\title{
Genealogical analyses of rabies virus strains from Brazil based on $\mathbf{N}$ gene alleles
}

\author{
M. B. HEINEMANN ${ }^{1}$, F. M. C. FERNANDES-MATIOLI ${ }^{2}$, A. CORTEZ ${ }^{1}$, \\ R. M. SOARES ${ }^{1}$, S. M. SAKAMOTO ${ }^{1}$, F. BERNARDI ${ }^{1}$, F. H. ITO ${ }^{1}$, \\ A. M. B. N. MADEIRA ${ }^{1}$ AND L. J. RICHTZENHAIN ${ }^{1 *}$ \\ ${ }^{1}$ Faculdade de Medicina Veterinária e Zootecnia. Universidade de São Paulo, São Paulo, Brasil \\ ${ }^{2}$ Instituto de Biociências. Universidade de São Paulo, São Paulo, Brasil
}

(Accepted 2 January 2002)

\section{SUMMARY}

Thirty rabies virus isolates from cows and vampire bats from different regions of São Paulo State, Southeastern Brazil and three rabies vaccines were studied genetically. The analysis was based on direct sequencing of PCR-amplified products of 600 nucleotides coding for the amino terminus of nucleoprotein gene. The sequences were checked to verify their genealogical and evolutionary relationships and possible implication for health programmes. Statistical data indicated that there were no significant genetic differences between samples isolated from distinct hosts, from different geographical regions and between samples collected in the last two decades. According to the HKA test, the variability observed in the sequences is probably due to genetic drift. Since changes in genetic material may produce modifications in the protein responsible for immunogenicity of virus, which may eventually cause vaccine failure in herds, we suggest that continuous efforts in monitoring genetic diversity in rabies virus field strains, in relation to vaccine strains, must be conducted.

\section{INTRODUCTION}

Rabies occurs in two different epidemiological patterns: urban rabies with the domestic dog as the main reservoir and transmitter, and sylvatic or rural rabies, with different wildlife species acting as reservoirs and or transmitters. In South America, the most important reservoir and transmitter of rural rabies is vampire bats, mainly Desmodus rotundus [1].

In São Paulo State, southeastern Brazil, the effective control programmes have reduced the number of dog rabies cases and most of the urban areas are free of rabies. However, the number of cases of bovine rabies is increasing along the territory of São Paulo State

* Author for correspondence: Departamento de Medicina Veterinária Preventiva e Saúde Animal, Faculdade de Medicina Veterinária e Zootecnia da Universidade de São Paulo. Prof Dr Orlando Marques de Paiva, 87. Cidade Universitária. São PauloSP. Brasil. 05508-000. and the disease remains a serious problem, mainly in northeast and southeast regions of São Paulo State, where at least 837 cases of bovine rabies and 80 cases of vampire bat rabies occurred between 1996 and 1999.

Rabies virus belongs to the genus Lyssavirus of the family Rhabdoviridae. Its genome is composed of a single-stranded, negative-sense, non-segmented RNA which encodes for five separate proteins designated as nucleoprotein $(\mathrm{N})$, phosphoprotein $(\mathrm{P})$, matrix protein $(\mathrm{M})$, glycoprotein $(\mathrm{G})$ and the RNA polymerase (L) [2].

The Lyssavirus genus is divided into seven genotypes. Genotype 1 includes the classical rabies virus strains found worldwide. The African rabies-related viruses are classified in three genotypes: type 2, Lagos bat virus which is the prototype strain of genotype 2, Mokola virus (genotype 3) and Duvenhage virus 
(genotype 4). The European rabies-related viruses are divided in two genotypes: the European bat lyssaviruses (genotypes 5 and 6). A seventh genotype is Australian bat lyssavirus.

Molecular epidemiology studies based on the RT-PCR (reverse transcriptase-polymerase chain reaction) technique, associated with direct sequencing, is a useful means of classification of animal viruses, including rabies virus, and provides a better understanding of epidemiological relationships [3].

Among the genes of rabies virus, the $\mathrm{N}$ gene, in particular, has been successfully employed in molecular epidemiology studies because since its sequences are most conserved [4], and its PCR products are therefore useful for diagnostic purposes. Also, there are many nucleoprotein sequences of all six Lyssavirus genotypes available in GenBank [5], which permits comparisons with new sequences and it presents an important role in the host immune response to Lyssavirus genotypes [6]. Analysis of the $\mathrm{N}$ gene sequences is also very informative in comparisons among related strains [7] and the 400 nucleotides in the $5^{\prime}$ end coding for the $\mathrm{N}$ protein can be used to determine the geographical distribution of the major virus lineages and are strongly recommended for phylogenetic analyses [5].

The present work reports the genealogical analyses of different rabies virus lineages using the genealogical methodology [8]. The nucleoprotein $\mathrm{N}$ gene sequences of rabies virus from São Paulo State, Brazil, were obtained by the employment of the RT-PCR technique associated with direct sequencing. The analyses were conducted considering three parameters - comparative analyses of rabies viruses isolated from bovine and vampire bats, of rabies virus collected in different localities of the geographical area, of rabies virus samples obtained in different years in the last two decades.

The aim of this work was the genetic characterization of the rabies virus lineages, considering the parameters described above, in order to contribute to health programmes and to elucidate the genealogical history of the lineages.

\section{METHODS}

\section{Virus isolates}

Twenty-two bovine brains and eight vampire bat (Desmodus rotundus) brains from São Paulo State, Brazil, were studied. They were tested for rabies virus by direct immunofluorescent antibody (dIFA) [9]. Table 1 shows the allelic samples of rabies virus analysed according to the hosts (VB for vampire bats and $\mathrm{B}$ for bovine), geographic origin, year of isolation and the GenBank access number. Figure 1 presents the geographical distribution of the samples.

\section{RNA extraction and RT-PCR}

Total RNA was extracted from infected brain tissue using TRIzol ${ }^{\mathbb{R}}$ reagent (GIBCO-BRL, Gaythersburg, MD, USA) as described by the manufacturer. For reverse transcription (RT), $7 \mu$ of extracted RNA was heated at $95{ }^{\circ} \mathrm{C}$ for $5 \mathrm{~min}$, and then cooled on ice. RT was carried out in $20 \mu \mathrm{l}$ of RT mixture containing $4 \mu \mathrm{l}$ of RT buffer (250 mm Tris-HCl, pH 8·3, $375 \mathrm{~mm} \mathrm{KCl}$, $15 \mathrm{mM} \mathrm{MgCl}_{2}$ ) (Gibco-BRL, USA), $10 \mathrm{~mm}$ of dNTPs; 10 pmol of specific nucleoprotein $\mathrm{N}$ sense primer $\left(5^{\prime}-\right.$ CTACAATGGATGCCGACAAGA-3', from nucleotide 66 to 86 in relation of PV strain, GenBank X03673), $10 \mathrm{~mm}$ of DTT, $200 \mathrm{U}$ of M-MulV RTase reverse transcriptase (Gibco-BRL) and milli-Q distilled water with $0.01 \%$ of DEPC as diluent. After incubation at $42{ }^{\circ} \mathrm{C}$ for $60 \mathrm{~min}, 5 \mu \mathrm{l}$ of cDNA product was added to the total volume of PCR mixture $(45 \mu \mathrm{l})$ containing $200 \mathrm{~mm}$ Tris- $\mathrm{HCl}, \mathrm{pH} 8 \cdot 0,500 \mathrm{~mm} \mathrm{KCl}$, $50 \mathrm{~mm} \mathrm{MgCl}_{2}, 5 \mathrm{~mm}$ dNTPs, 10 pmol of each specific nucleoprotein $\mathrm{N}$ primer (sense 5'-CTACAATGGATGCCGACAAGA-3', and anti-sense 5'-CCTCAAAGTTCTTGTGGAAGA-3', nucleotides 849-869 in relation of PV strain, GenBank X03673), 1.25 U of Taq DNA polymerase (Gibco-BRL) and milli-Q distilled water as diluent.

After an initial heating at $95^{\circ} \mathrm{C}$ for $5 \mathrm{~min}$, the amplification reached 35 cycles of $45 \mathrm{sec}$ at $94{ }^{\circ} \mathrm{C}$, $60 \mathrm{sec}$ at $55^{\circ} \mathrm{C}, 90 \mathrm{sec}$ at $72{ }^{\circ} \mathrm{C}$ and followed by a final heating at $72{ }^{\circ} \mathrm{C}$ for $10 \mathrm{~min}$. Amplifications were performed in a PTC-200 Peltier Thermal Clycer (MJ Research, Waltham, MA, USA). All PCR products were analysed on $1.2 \%$ agarose gels stained by ethidium bromide.

\section{Nucleotide sequencing}

Amplified DNA products with expected molecular size (804 bp) were excised from the gel and purified through a commercial kit $\left(\mathrm{GFX}^{\mathrm{TM}}\right.$ PCR DNA and Gel Band Purification Kit, Amersham Pharmacia Biotech Inc, Piscataway, NJ, USA). Sequencing reactions were performed by the dideoxynucleotide chain termination method using the BigDye ${ }^{\mathrm{TM}} \mathrm{TM}$ 
Table 1. Strains of rabies virus with their respective host species, year and region of isolation

\begin{tabular}{|c|c|c|c|c|c|}
\hline Strain & Host & Municipality & Year & Region & GenBank \\
\hline B1 & Bovine & Cajatí & 1986 & Vale do Ribeira & AF357316 \\
\hline B2 & Bovine & No information & 1986 & No information & AF357296 \\
\hline B3 & Bovine & Bernardino de Campos & 1988 & Vale do Ribeira & AF357300 \\
\hline B4 & Bovine & Pirajú & 1989 & Vale do Ribeira & AF357301 \\
\hline B5 & Bovine & Pindamonhangaba & 1989 & Vale do Paraíba & AF357302 \\
\hline B6 & Bovine & Pindamonhangaba & 1989 & Vale do Paraíba & AF357303 \\
\hline B7 & Bovine & Pirajú & 1989 & Vale do Ribeira & AF357304 \\
\hline B8 & Bovine & Pindamonhangaba & 1989 & Vale do Paraíba & AF357305 \\
\hline B9 & Bovine & Pindamonhangaba & 1989 & Vale do Paraíba & AF357306 \\
\hline B10 & Bovine & Pindamonhangaba & 1990 & Vale do Paraíba & AF357286 \\
\hline B11 & Bovine & São Joaquim da Barra & 1991 & No information & AF357287 \\
\hline B12 & Bovine & Apiaí & 1991 & Vale do Ribeira & AF357288 \\
\hline VB1 & Desmodus rotundus & Taubaté & 1992 & Vale do Paraíba & AF357309 \\
\hline B13 & Bovine & São Roque & 1994 & Vale do Paraíba & AF357289 \\
\hline VB2 & Desmodus rotundus & Guaratinguetá & 1994 & Vale do Paraíba & AF357310 \\
\hline VB3 & Desmodus rotundus & Guaratinguetá & 1994 & Vale do Paraíba & AF357311 \\
\hline VB4 & Desmodus rotundus & Guaratinguetá & 1994 & Vale do Paraíba & AF357312 \\
\hline VB5 & Desmodus rotundus & Guaratinguetá & 1994 & Vale do Paraíba & AF357313 \\
\hline VB6 & Desmodus rotundus & Taubaté & 1994 & Vale do Paraíba & AF357314 \\
\hline VB7 & Desmodus rotundus & Taubaté & 1995 & Vale do Paraíba & AF357315 \\
\hline B14 & Bovine & Taubaté & 1998 & Vale do Paraíba & AF357290 \\
\hline B15 & Bovine & Jacareí & 1998 & Vale do Paraíba & AF357291 \\
\hline B16 & Bovine & Santo Antônio do Pinhal & 1998 & Vale do Paraíba & AF357292 \\
\hline B17 & Bovine & Taubaté & 1998 & Vale do Paraíba & AF357293 \\
\hline B18 & Bovine & Taubaté & 1998 & Vale do Paraíba & AF357294 \\
\hline VB8 & Desmodus rotundus & Taubaté & 1998 & Vale do Paraíba & AF357285 \\
\hline B19 & Bovine & Taubaté & 1998 & Vale do Paraíba & AF357295 \\
\hline B20 & Bovine & Jacareí & 1998 & Vale do Paraíba & AF357297 \\
\hline B21 & Bovine & Pariquera-Açu & 1999 & Vale do Ribeira & AF357298 \\
\hline $\mathrm{B} 22$ & Bovine & Pariquera-Açu & 1999 & Vale do Ribeira & AF357299 \\
\hline
\end{tabular}

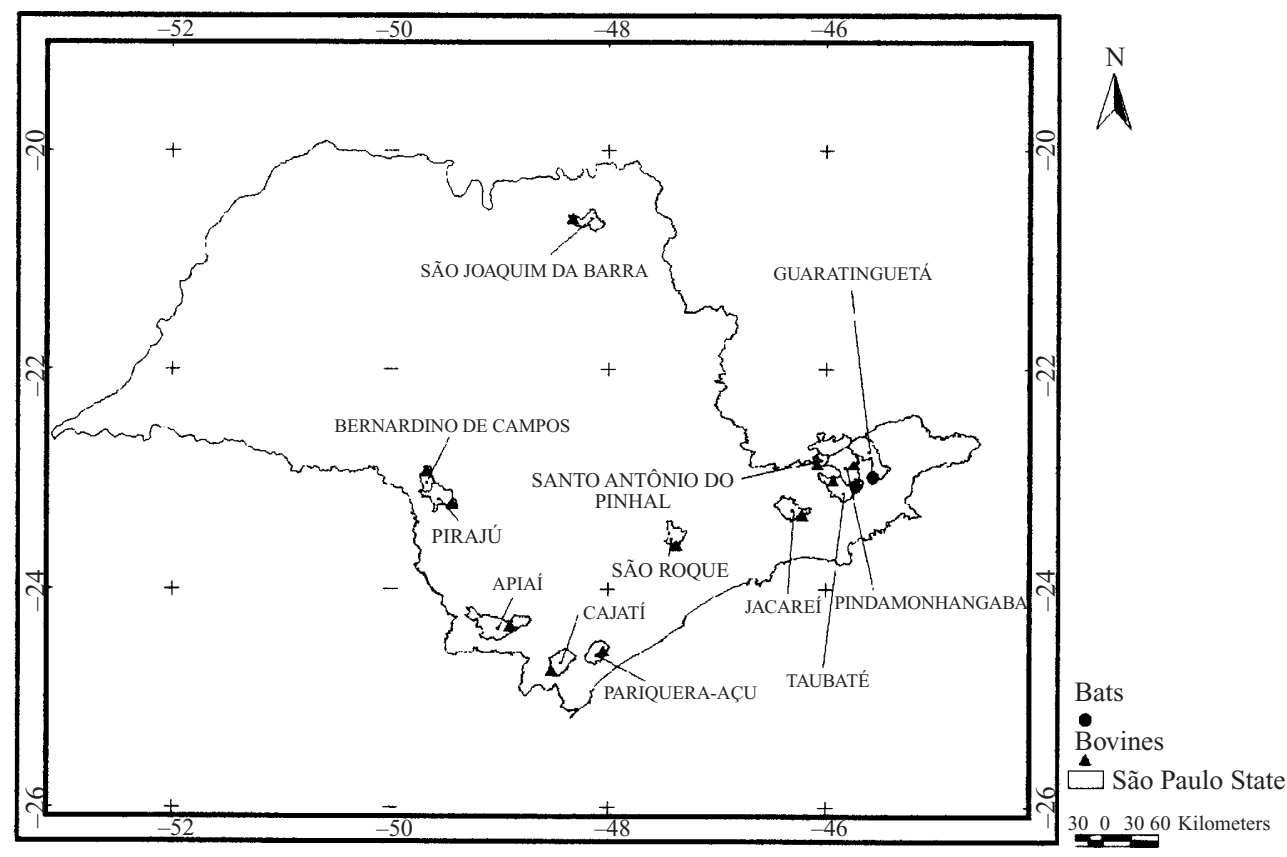

Fig. 1. Localization of the rabies virus isolates from different municipalities from São Paulo State, Southeastern Brazil. 
Table 2. Nucleotide diversity within the categories analysed

\begin{tabular}{|c|c|c|c|c|c|c|}
\hline & No.* & $\mathrm{M} \dagger$ & $\mathrm{k} t$ & $V(k) o \S$ & $V(k) e^{* *}$ & $P i \oplus$ \\
\hline Bats & 7 & 27 & $12 \cdot 857$ & $12 \cdot 368$ & $31 \cdot 313$ & $0 \cdot 02189$ \\
\hline Bovines & 22 & 59 & $12 \cdot 537$ & $3 \cdot 169$ & $31 \cdot 42$ & $0 \cdot 02129$ \\
\hline Year 86/91 & 12 & 33 & $8 \cdot 439$ & $2 \cdot 946$ & $14 \cdot 716$ & $0 \cdot 01429$ \\
\hline Year 92/99 & 17 & 49 & $14 \cdot 221$ & $5 \cdot 345$ & $39 \cdot 675$ & 0.02419 \\
\hline PB & 21 & 52 & $13 \cdot 389$ & 3.984 & $39 \cdot 508$ & $0 \cdot 02276$ \\
\hline $\mathrm{RB}$ & 7 & 25 & $9 \cdot 714$ & $7 \cdot 252$ & $18 \cdot 488$ & $0 \cdot 01645$ \\
\hline
\end{tabular}

* No., sample size; $\uparrow M$, number of mutation; $₫ k$, average number of nucleotide differences; $\S V(k) o$, observed variance of $k ; * * V(k) e$, expected variance of $k$; $\uparrow P i$, nucleotide diversity.

Terminator (Applied Biosystems, CA, USA) and the sequences were determined with an automated sequencer (ABI model 377, Applied Biosystems, CA, USA) according to the manufacturer's instructions. Sequencing was performed in both directions using the cited primers. All sequences were performed at least three times, so as to prevent any distrust about the correct sequences.

\section{Genealogical analysis}

The nucleotide sequences of $600 \mathrm{bp}$ in the $5^{\prime}$ end coding for $\mathrm{N}$ protein obtained from 30 isolates were aligned by eye using the softwares Clustal X [10], SeqPup v.0.6f [11] and sequence Navigator v.1.01 [12]. The putative amino acid sequence of the PCR products was automatically translated using the programme MacClade v.3.01 [13] for Macintosh.

Statistical data involving nucleotide diversity and sequence variability were obtained using the software DnaSP v.3.51 [14]. Values of the following parameters were estimated: nucleotide diversity $(P i)$, average number of nucleotide substitution per site $(D x y)$, number of net substitution per site between populations $(D a)$ [15], average number of nucleotide differences $(k)[16,17]$. In the gene flow analyses, the estimators GammaSt and Nm [18,19] were employed.

The genealogical analyses were conducted in three major steps. First, the total sample was split into categories according to the hosts (bovines and vampire bats); the total sample was split according to geographic origin (PB for Vale do Paraíba and RB for Vale do Ribeira), except the sample B2 (see Table 1). The total sample was then split according to the isolation date (1986-91 and 1992-9). Since the sample VB8 had shown an unexpected behaviour in the genealogies obtained (see results and discussion), we removed it from the analyses. For the three parameters analysed, the HKA test [20] for silent substitutions was applied in the allelic sample assuming a $\chi^{2}$ distribution with 1 degree of freedom, with $P=0 \cdot 05$. After the analyses described above and according to the results obtained, we carried out a similar approach involving two major groups formed by: group (1) CVS, PV, SAD B19 and VB8; group (2) the other sequences.

We employed software PAUP* v.4.0b3a [21] with exhaustive search and equal weighting in the maximum parsimony analyses. The consistency index (CI) [22] was obtained with MacClade v.3.03 [13]. Bootstrap values [23] were obtained using the heuristic search using 500 replicates. Sequences from SAD B19, PV, CVS strains, which are used in vaccines, were obtained from GenBank (M31046, AF357308, AF357308, respectively). The allelic trees were drawn out with the programme TreeView v.1.4 [24].

\section{RESULTS}

All samples analysed were rabies virus-positive by dIFA and RT-PCR assays. No gaps were detected in the allelic sequences. The statistical results involving the alleles comparison, both within and between categories, are shown in Tables 2 and 3, respectively. Considering the three categories (hosts, geographical locality and year of isolation), the nucleotide diversity $(P i)$ and the average number of nucleotide differences $(k)$ were similar within and between groups. No fixed differences (FD) were found between the compared categories, on the other hand an important number of shared mutations (SM) were observed. Furthermore, the $P i, k, D x y, D a$, the high $N m$ values, and the low GammaSt results indicated a great similarity between the groups in each category (Tables 2,3 ). 
Table 3. Nucleotide diversity between the categories analysed

\begin{tabular}{lllllllllll}
\hline \hline & $\mathrm{p} 1 \mathrm{~m} 2$ & $\mathrm{p} 2 \mathrm{~m} 1$ & $\mathrm{FD}$ & $\mathrm{SM}$ & $k(t)$ & $P i(t)$ & $D x y$ & $D a$ & Nm & GammaSt \\
\hline Bovine $\times$ Bat & 41 & 9 & 0 & 18 & $12 \cdot 935$ & $0 \cdot 02117$ & $0 \cdot 02156$ & $0 \cdot 0004$ & $11 \cdot 12$ & $0 \cdot 05752$ \\
Year 86-91 × Year 92-99 & 19 & 35 & 0 & 14 & $13 \cdot 074$ & $0 \cdot 02117$ & $0 \cdot 02179$ & $0 \cdot 00291$ & $4 \cdot 53$ & $0 \cdot 09941$ \\
PB $\times$ RB & 37 & 10 & 0 & 15 & $12 \cdot 357$ & $0 \cdot 02126$ & $0 \cdot 0206$ & $0 \cdot 00134$ & $8 \cdot 22$ & $0 \cdot 05733$ \\
\hline \hline
\end{tabular}

p1m2, comparison between polymorphic sites in group 1 and monomorphic in group 2; p $2 \mathrm{~m} 1$, comparison between polymorphic sites in group 2 and monomorphic in group 1; FD, fixed differences; SM, shared mutation; $k(t)$, average number of nucleotide differences; $P i(t)$, nucleotide diversity; $D x y$, average number of nucleotide substitution per site; $D a$, number of net substitution per site between populations; $\mathrm{Nm}$, Nei's pseudoparameter; GammaSt, gamma estimation of gene flow.

Table 4. Nucleotide diversity between the groups analysed

\begin{tabular}{lllllllllll}
\hline \hline Groups & $\mathrm{p} 1 \mathrm{~m} 2$ & $\mathrm{p} 2 \mathrm{~m} 1$ & $\mathrm{FD}$ & $\mathrm{SM}$ & $k(t)$ & $P i(t)$ & $D x y$ & $D a$ & $N m$ & GammaSt \\
\hline $1 \times 2$ & 59 & 64 & 52 & 9 & 12.935 & 0.02117 & 0.01859 & 0.121 & 0.43 & 0.5353 \\
\hline \hline
\end{tabular}

p1m2, comparison between polymorphic sites in group 1 and monomorphic in group 2; $2 \mathrm{~m} 1$, comparison between polymorphic sites in group 2 and monomorphic in group 1; FD, fixed differences; SM, shared mutation; $k(t)$, average number of nucleotide differences; $P i(t)$, nucleotide diversity; $D x y$, average number of nucleotide substitution per site; $D a$, number of net substitution per site between populations; $\mathrm{Nm}$, Nei's pseudoparameter; GammaSt, gamma estimation of gene flow.

Table 5. Results of HKA test for all categories and groups

\begin{tabular}{llll}
\hline \hline Categories & $\chi^{2 *}$ & $P$ value $\dagger$ & Significant \\
\hline Bovine $\times$ Vampire Bat & 0.005 & 0.9443 & No \\
Year 86/91 $\times$ Year 92/99 & 0.084 & 0.7725 & No \\
PB $\times$ RB & 0.007 & 0.9347 & No \\
Group $1 \times 2$ & 0.269 & 0.6042 & No \\
\hline \hline
\end{tabular}

*Value of $\chi^{2} ; \dagger P=0 \cdot 05$

The statistical analyses involving the groups 1 (SAD B19, CVS and PV plus VB8) and 2 (other alleles) are presented in Table 4 . Note that this time the number of fixed differences was increased perceptibly if compared to the category analyses. This change was also followed by a decrease of the shared mutations between the groups and of the values of the gene flow estimators. These results indicate that the groups 1 and 2 could be regarded as significantly different groups. The results of the HKA test coroborated the data obtained in the categories and in the groups analyses. According to this test, there is no significant difference between the allelic regions studied (Table 5), thus, the nucleotide variability found could be due to the genetic drift.

In the maximum parsimony analyses of the nucleotide sequences, 20 trees with 362 steps were found. The strict consensus tree was computed from the shortest trees and represents the genealogy involving

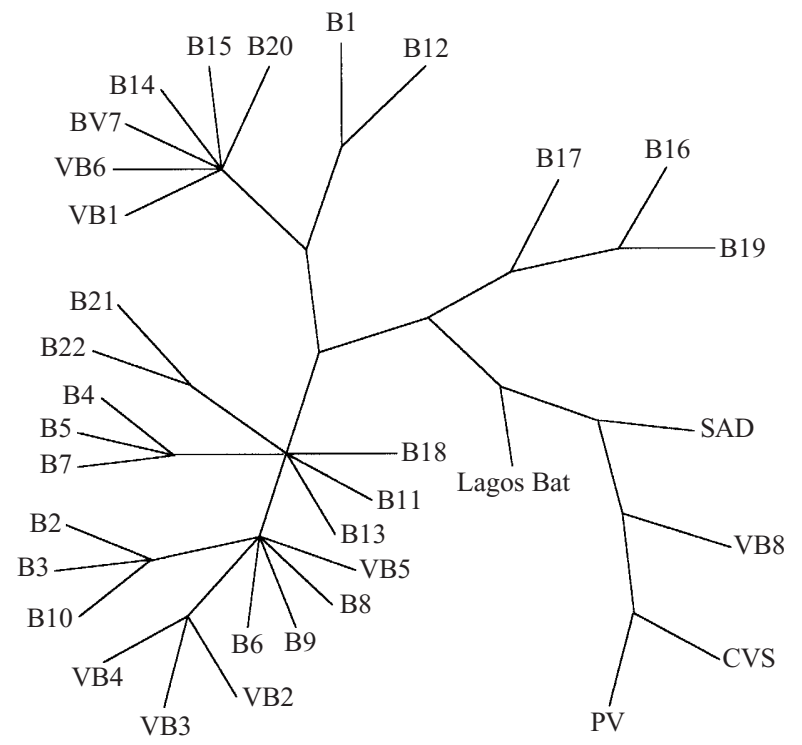

Fig. 2. Maximum-parsimony unrooted tree based on the nucleotide sequence of the nucleoprotein gene of rabies virus. The CI value was equal to $80 \%$.

the $\mathrm{N}$ gene alleles. Figure 2 shows the unrooted allelic tree. In the maximum parsimony analyses involving the amino acid sequences, 100 trees with 72 steps were found. After the translation, a conspicuous number of branches collapsed. The strict consensus unrooted amino acid tree is shown in Figure 3.

Bootstrap values of $100 \%$ were found in the nodes that separate the strains of rabies virus (genotype 1) 


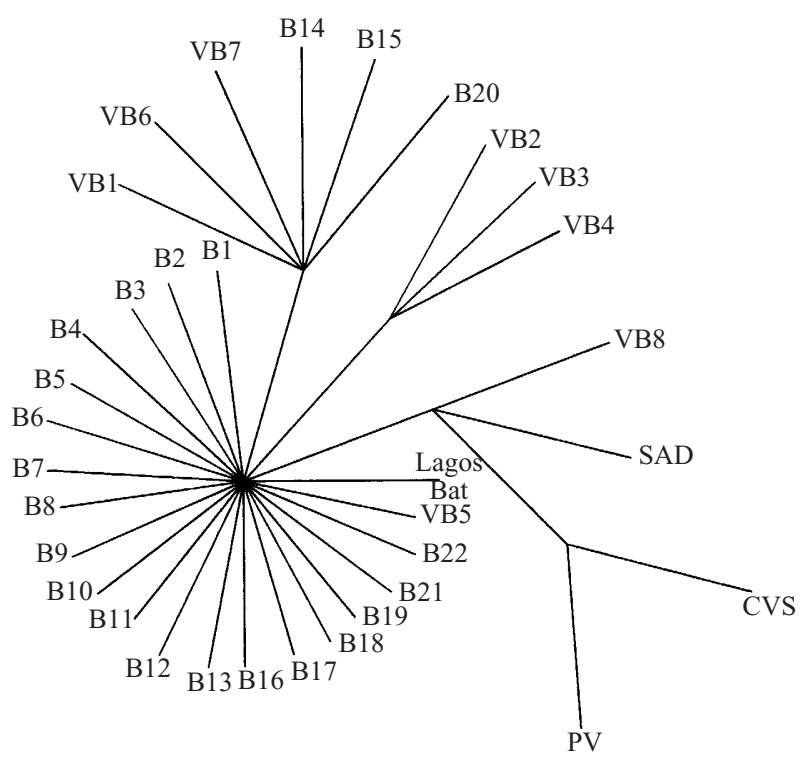

Fig. 3. Maximum-parsimony unrooted tree based on the amino acid sequence of the nucleoprotein gene of rabies virus.

from the external group (genotype 2-Lagos Bat Virus), in the node of the divergence between groups 1 and 2 and in the node that divides the branches of the PV/CVS strains from that of the SAD B19 and VB8 strains.

\section{DISCUSSION}

Economic losses in Brazil related to rabies in herbivores are around US $\$ 15000000 \cdot 00 /$ year, and almost 40 thousand bovines are lost each year [25, 26]. The uncontrolled increase in the Desmodus rotundus population, the main species involved in rabies transmission to bovines, due to the migration of the population and to the increase in the number of natural and artificial shelters, has contributed to the increasing number of outbreaks in the state of São Paulo, since the beginning of the 1980s [26].

The allele sequences of the nucleoprotein $\mathrm{N}$ gene obtained from rabies virus strains revealed the presence of specific sites that may offer information for the assessment of genetic correlation between the strains, enabling the reconstruction of their genealogy.

The unrooted strict consensus nucleotide tree (Fig. 2) presented the consistency index (CI) equal to $80 \%$. Since the CI evaluates the degree of homoplasy of a tree, the present results indicate that the data are well-adequated to the proposed tree topology. The polytomies in the strict consensus tree could be evidence of a high evolutionary conservation of the en- coding genes analysed. Alternatively, it could be indicating simultaneous dispersion centres and/or events.

The topology of the tree obtained based on the protein sequences (Fig. 3) shows a large amount of collapsed branches, probably as a result of the occurrence of synonymous mutations in the gene sequences. Since non-synonymous mutations may alter structural protein structure and function in a deleterious way, in the present case, the great number of polytomies in the amino acid tree was expected.

In the maximum parsimony unrooted tree based on the amino acid sequence (Fig. 3) the group made up of strains CVS, PV, SAD B19 and VB8 (group 1) could be separated from the rest of the strains (group 2). In relation to group 2, although we may separate the strains into three subgroups, no segregation was observed in relation to geographic region, time or species. No difference between the strains circulating in the categories of bovines and bats was expected. The bat is, in the state of São Paulo, the main agent in the transmission of rabies to bovines, which are located at the end of rabies transmission chains in rural areas $[1,27]$.

Therefore, it is expected that the spectrum of strains that infect bats may be related to the one that infects bovines. This supposition is reinforced by data obtained in the intercategory analyses, which produced GammaSt (0.0572) and $N m$ (11.2) (Table 3) estimated values that indicate that the virus strains should be considered as a single evolutionary unit.

The value of the estimator $D x y$, which informs the average number of nucleotide substitutions per site between the categories, was equal to $2 \cdot 15 \%$. This is an expected value for categories that behave as a panmictic unit [28]. Dxy values estimate the probability of allele identity by lineage, that is, the result (Table 3) is the probability that the alleles of each category originated by direct lineage within the same category, and not due to 'migration'. This fact leads to the conclusion that a single evolutionary unit is being analysed. The absence of fixed differences between these two categories associated with the low value of the number of net nucleotide substitutions per site (Table 3) reinforce the evidence that the strains from these groups form a single evolutionary group.

Results obtained in this trial, in relation to the circulation of the strains in the hosts, are similar to those obtained by Mattos et al. [29], who observed that 12 strains isolated from bovines in Venezuela were closely related ( $98 \%$ homology) to isolates from 
vampire bats in Latin America. Tordo et al. [30], working with Brazilian strains, distinguished two groups, one comprising wild rabies (bovines and bats) and the other, dog strains (urban rabies). These authors concluded that there are two distinct variants, one for the wild cycle and the other for the urban cycle.

Favoretto et al. [31], who also studied Brazilian strains using monoclonal antibodies determined that $100 \%$ of the strains isolated from bovines belong to the Desmodus rotundus variant, what is in agreement with the results of the present study.

No differences were observed between the different strains isolated in the different time periods (1986-91 and 1992-9 (Table 3)). The gene flow estimator $\mathrm{Nm}$ equal to 4.53 indicates that there are no significant differences between the two categories. The results of the present trial corroborate those reported by several authors [5, 7, 32-34], who, in general, did not observe differences along the time between the distinct isolates of rabies virus.

In relation to the categories based on geographical distribution, it was not possible to demonstrate differences between the strains from Vale do Paraíba and Vale do Ribeira. As presented in Figure 3, several strains segregate together, regardless of their origin. This observation is reinforced by data from population analyses between the two categories, in which the $\mathrm{Nm}$ was $8 \cdot 2$ (Table 3 ). This value indicates that these two categories also form a single evolutionary unity.

Although data obtained here do not indicate variability related to the different geographical locations, there are reports which demonstrate that this may not be the general rule. Nadin-Davis et al. $[35,36]$, did not find variations between lineages from different hosts, but demonstrated that there was a very clear and consistent difference between rabies viruses from different geographical regions in Ontario province, Canada. Kissi et al. [5] and Smith et al. [33] also differentiated rabies virus strains according to their geographical distribution throughout the world.

Souza et al. [37] studied the serological and biological aspects of the strains isolated from Desmodus rotundus captured in Vale do Paraíba (SP). Two strains of their study were also analysed in the present trial (VB2 and VB3). Those authors reported that the strains, when serologically compared with fixed strains of rabies, presented differences in reactivity, that is, antisera from strains PV and CVS could only neutralise strains VB2 and VB3 in low dilutions. In spite of the present focus on nucleoprotein $\mathrm{N}$ and the neutralization had being attributed mainly to antibodies directed against glycoprotein $\mathrm{G}$, our results are in agreement with those obtained by Souza et al. [37]. As shown in the amino acid tree, the strains VB2 and VB3 segregate separately (Fig. 3).

Group 1 (PV, CVS, SAD B19, VB8) is significantly separated from the other strains and presents a monophyletic profile. This is very intriguing, since strain VB8 is an isolate from a vampire bat. Nucleotide variability data from groups 1 and 2 (Table 4) indicate the occurrence of 52 fixed mutations, that shows a large absolute difference between the strains from both groups. An $\mathrm{Nm}$ value of 0.43 and a GammaSt value of 0.53 show that the groups 1 and 2 could not be considered as a single evolutionary unity.

Reasonable hypotheses to explain the position of strain VB8 in the proposed genealogy could be either that the VB8 strain is a new variant, and its strain is originated from a recent common ancestry of the strains analysed, or VB8 strain is a variant from a non-vampire bat. The hypothesis is reinforced by Tordo et al. [38], who identified strains isolated from a non-vampire bat (Tadarida brasiliensis) in Mexico, which were very close to the canine variants. Favoretto et al. [31], typing rabies virus strains isolated from non-vampire bats using monoclonal antibodies observed cross-reactivity with strains isolated from Desmodus rotundus (variant 3), Tadarida brasiliensis (variant 4) and Lasiurus cinereus (variant 6). They also demonstrated the occurrence of four antigenic profiles not compatible with the existing ones. These data confirms the great diversity of the variants found in non-vampire bats, and therefore the VB8 strain may originate from an insectivorous bat.

Alternatively, the VB8 isolate may be a dog variant that has transmitted to a bat. For this, an intimate interaction between a wild or domestic dog and a vampire bat would be needed. However, this hypothesis lacks credibility because it relies on the complicated process involving the survival of a vampire bat after a dog bite followed by the elimination of rabies virus and then the continuation of virus transmission to other vampire bats.

Results of the HKA test (Table 5), performed with all artificial groups, including groups 1 and 2, show that there is no significant difference between the groups in relation to nucleotide substitution. These results indicate that the differential selective pressure hypothesis in the different regions of the sequences 
studied ( $5^{\prime}$ end coding for $\mathrm{N}$ protein) should be rejected, and that variability observed is probably due to genetic drift. Similar results were obtained by Kissi et al. [5], who suggested that there is no evidence of cumulative effects for the non-synonymous mutations and eventual changes in the epitopes, certainly due to the intense conservation in protein $\mathrm{N}$ evolution [39].

Final analyses of data presented here indicates the need for continuous efforts in monitoring gene diversity in field strains, in relation to vaccine strains, since changes in genetic material may produce modifications in the proteins responsible for immunogenicity of virus strains, which may eventually cause vaccine failures in herds.

\section{ACKNOWLEDGEMENTS}

We wish to thank Dr Arthur Gruber and Dr Fernando Ferreira for technical assistance. This work was supported by FAPESP (grant no. 96/07723-0).

\section{REFERENCES}

1. Acha PN, Szyfres B. Zoonosis y enfermidades transmissibles comunes al hombre y a los animales, 2nd ed. Washington: Organizacion Panamericana de la Salud (PHO), 1986: 860.

2. Kawai A, Morimoto K. Functional aspects of lyssavirus proteins. Curr Top Microbiol Immunol 1994; 187: 27-42.

3. Smith J, McElhinney LM, Heaton PR, Black EM, Lowings JP. Assessment of templete quality by the incorporation of an internal control into a RT-PCR for the detection of rabies and rabies-related viruses. J Virol Meth 2000; 84: 107-15.

3. Haas L. Molecular epidemiology of animal virus diseases. J Vet Med Serie B 1997; 44: 257-72.

4. Sacramento D, Bourhy H, Tordo N. PCR technique as an alternative method for diagnosis and molecular epidemiology of rabies virus. Mol Cell Probes 1991; 5: 229-40.

5. Kissi B, Tordo N, Bourhy H. Genetic polymorphism in the rabies virus nucleoprotein gene. Virology 1995; 209: 526-37.

6. Dietzschold B, Wang H, Rupprecht CE, et al. Introduction of protective immunity against rabies by immunization with rabies ribonucleoprotein. PNAS USA 1987; 48: 9165-9.

7. Bourhy H, Kissi B, Tordo N. Taxonomy and evolutionary studies on Lyssavirus with special reference to Africa. Onderstepoort J Vet Res 1993; 60: 277-82.

8. Hudson RR. Gene and the coalescent process. In: Futuyma D, Antonovice J, eds. Oxford surveys in evolutionary biology. Oxford: Oxford University Press, 1991.
9. Dean DJ, Abelseth MK, Atanasiu P. The fluorescent antibody test. In: Laboratory techniques in rabies. World Health Organization, 4th ed. Geneva: WHO, 1996: 88-93.

10. Thompson EA. Crossover counts and likehood in multipoint linkage analysis. J Math Appl Med Bio 1987; 4: 93-108.

11. Gilbert DG. SeqPup v.0.6f. A biosequence editor \& analysis application, 1995.

12. Perkin Elmer. Sequence Nagivator ${ }^{\mathrm{TM}}$ v.1.0.1. Applied Biosystems Inc, 1994.

13. Maddison WP, Maddison DR. MacClade v.3.0.3. Sinauer Associates Inc. Publishers, Sunderland, MA. USA, 1992.

14. Rozas J, Rozas R. DNAsp version 3.51: a novel software package for extensive molecular population genetics analyzes. Comp Applicat Bioscien 1997; 13: 307-11.

15. Nei M. Molecular evolucionary genetics. New York: Columbia University Press, 1987: 512.

16. Tajima F. Evolutionary relationship of DNA sequences in finite populations. Genetics 1983; 105: 437-60.

17. Tajima F. Simple methods for testing the molecular evolutionary clock hypothesis. Genetics 1993; 135: 599-607.

18. Nei M. Evolution of the human races at the gene level. In: Bonne-Tamir B, Cohen T, Goodmann RM, eds. Human genetics, part A: the unfolding genome. New York: Alan R. Liss, 1982.

19. Kimura M, Maruyama T. Pattern of neutral polymorphism in a geographically structured population. Genet Res 1971; 18: 123-31.

20. Hudson RR, Kreitman M, Aguadé M. A test of neutral molecular evolution based on nucleotide data. Genetics 1987; 116: 153-9.

21. Swofford DL. Paup v.3.1.1. Phylogenetics analysis using parsimony. Smithsonian Institution, 1993.

22. Felsenstein J. Cases in which parsimony and compatibility methods will be positively misleading. Syst Zool 1978; 27 : 401-10.

23. Efron B. Bootstrapping methods: another look at the jackknife. Ann Stat 1979; 7: 1-26.

24. Page RDM TreeView: an application to display phylogenetic trees on personal computers. Comp Appl Biosci 1996; 12: 357-8.

25. Ministério da agricultura e do abastecimento. Boletim de Defesa Sanitária Animal. Edição 2000, Brasília DF, 1997; 30, n.1-4: 142.

26. Kotait I. Controle da raiva em herbívoros. São Paulo, São Paulo: Instituto Pasteur, Manual Técnico do Instituto Pasteur, 1998: 15.

27. Baer GM. Vampire bat and bovine paralytic rabies. In: Baer GM, ed. The natural history of rabies, 2nd edn. Boca Raton: CRC Press, 1991: 389-403.

28. Hartl DL, Clark AG. Principles of population genetics, 2nd edn. Sunderland: Sinauer Associates, 1989: 457.

29. Mattos CA, Mattos CC, Smith JS, et al. Genetic characterization of rabies field isolates from Venezuela. J Clin Microbiol 1996; 34: 1553-8.

30. Tordo N, Badrane H, Bourhy H, Sacramento D. 
Molecular epidemiology of lyssaviruses: focus on the glycoprotein and pseudogenes. Onderstepoort $\mathbf{J}$ Vet Res 1993; 60: 315-23.

31. Favoretto SR, Mattos CC, Carrieri ML, et al. Caracterização de variantes no Brasil e países vizinhos. In: Seminário Internacional de Raiva. São Paulo: Instituto Pasteur São Paulo, 2000: 59-61.

32. Sacramento D, Badrane $\mathrm{H}$, Bourhy $\mathrm{H}$, Tordo $\mathrm{N}$. Molecular epidemiology of rabies virus in France: comparision with vaccine strains. J Gen Virol 1992; 73: 1149-58.

33. Smith JS, Orciari LA, Yager PA, Seidel HD, Warner CK. Epidemiologic and historical relationships among 87 rabies virus isolates as determined by limited sequence analysis. J Infect Dis 1992; 166: 296-307.

34. Von Teichman BF, Thomson GR, Meredith CD, Nel LH. Molecular epidemiology of rabies virus in South Africa: evidence for two distinct virus group. J Gen Virol 1995; 76: 73-82.
35. Nadin-Davis SA, Casey GA, Wandeler A. Identification of regional variants of the rabies virus within the Canadian province of Ontario. J Gen Virol 1993; 74 : 829-37.

36. Nadin-Davis SA, Casey GA, Wandeler A. A molecular epidemiological study of rabies virus in central Ontario and western Quebec. J Gen Virol 1994; 75: 2575-83.

37. Souza MCAM, Bernardi F, Ito FH. Epidemiology of rabies: biological and serological aspects of rabies in vampire bats Desmodus rotundus (E. Geoffroy) captured in Vale do Paraíba, southeastern region of Brazil. Arq Instit Bio São Paulo 1997; 64: 91-101.

38. Tordo N, Sacramento D, Badrane H, et al. Genetic diversity of lyssaviruses: implications in vaccinology. In: Seminário Internacional de Raiva. São Paulo: Instituto Pasteur São Paulo, 2000: 26-7.

39. Belsel PA, Rowe JA, Fitch WM, Nichols ST. Phosphoprotein and nucleocapsid protein evolution of vesicular stomatitis virus New Jersey. J Virol 1990; 64: 2498-504. 